\title{
The Role of Vitamin C on the Structural Changes of Male Albino Rats Kidney Induced by Tramadol
}

\author{
Dr. Rana M. Ahmad ${ }^{a}$, Prof. Dr. Abduljabbar Y. AL-Hubaity ${ }^{a}$, Dr. Nadwa S. Alazow ${ }^{\text {b }}$ \\ ${ }^{a}$ Department of Anatomy, ${ }^{b}$ Department of Pathology, College of Medicine, University of Mosul, Mosul, Iraq. \\ Correspondence: Rana M. Ahmad. dr.rana.mustafa.76@gmail.com
}

(Ann Coll Med Mosul 2019; 41 (1):57-62).

Received: 24 $4^{\text {th }}$ Mar. 2019; Accepted: $27^{\text {th }}$ May 2019.

\begin{abstract}
Aim of study: The aim of this work is to detect the toxic effects of tramadol on the microscopic structure of the kidneys of adult male albino rats, and the possible protective role of vitamin $\mathrm{C}$ against these toxic effects.

Method: Thirty adult albino rats are used in this study. The animals were divided into three equal groups: Group A (control group): Animals were injected daily with normal saline for 4 weeks. Group B (Tramadol treated group) (TGI): Animals were injected daily with tramadol in a dose of $50 \mathrm{mg} / \mathrm{kg} \mathrm{b.wt} \mathrm{for} 4$ weeks. Group C (group treated with tramadol+vitamin C) (TGII): Animals were injected with vitamin C in a dose $100 \mathrm{mg} / \mathrm{Kg} / \mathrm{b}$.wt half hour prior to tramadol injection in the same dose as in group B for 4 weeks. The injection was given intraperitoneally for all animals. At the end of the experiments, the rats were anaesthetized by ether, then killed. After that kidneys removed, fixed in formaldehyde and processed for microscopic examination.
\end{abstract}

Result: Tramadol causes shrinkage of renal glomeruli with widening of bowman's space. Renal tubules showed hydropic degeneration and vacuolization of their epithelial cells. Infiltration of mononuclear cells along with Hyaline cast is seen within the degenerated tubules. Giving vitamin C prior to tramadol injection results in improvement in the microscopical structure of kidney mainly in glomeruli and tubules.

Conclusion: Using tramadol caused damage to renal glomeruli and tubules in renal cortex. The addition of vitamin C partially improved the histological structure of kidney.

Keywords: Tramadol, Rats kidney, vitamin C.

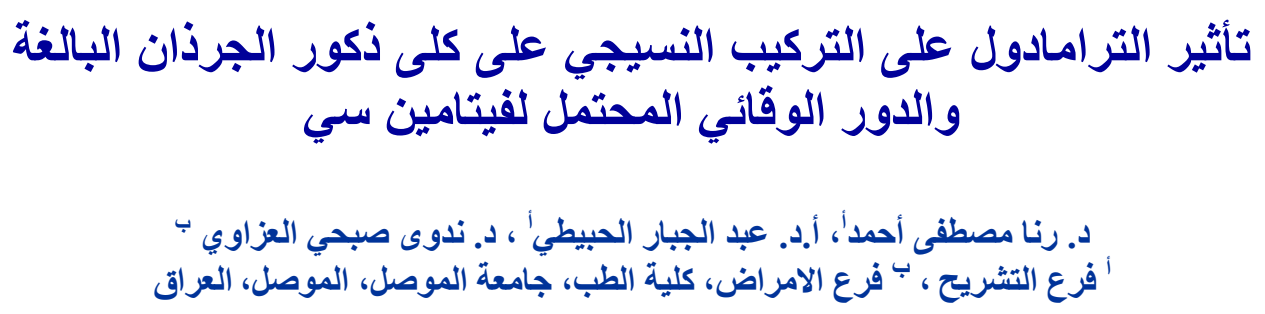

الخلاصة

اللهاف: للكثف عن التأثيرات السمية للترامادول على أنسجة الكلية لذكور الجرذان البيضاء البالغة، والدور الوقائي المحتمل لفيتامين سي ضد هذه السمية.

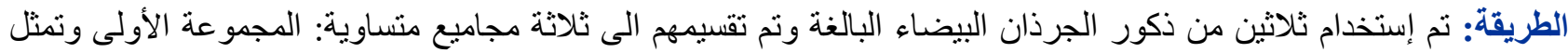

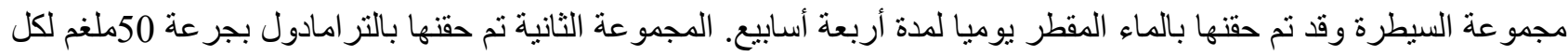

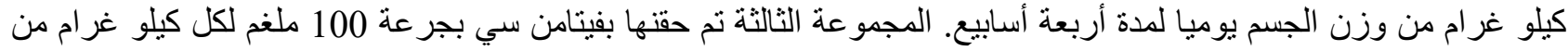

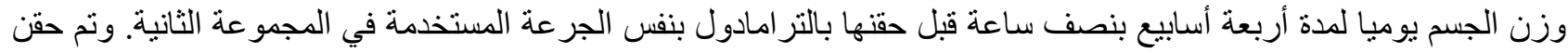
جميع الحيو انات في غشاء الجياء البريتون. وفي نهاية التجربة تم تخدير الحيو انات بمادة الايثز ، ثم قتلها. بعد ذللك تم إز الة الكلية وتثنيتها بالفورمالديهايد ثم أعدت للفحص المجهري. 


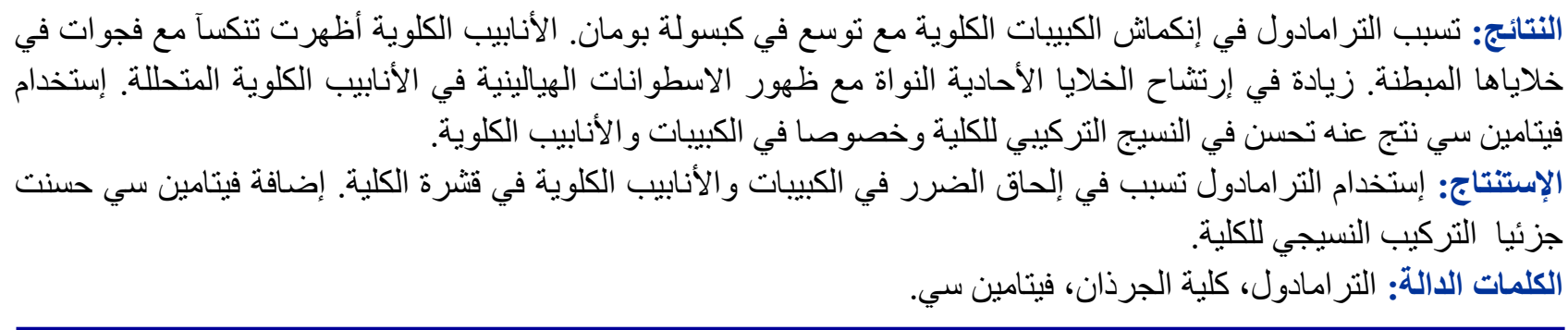

\section{INTRODUCTION}

A ddiction is a growing public and health problem widespread in spite of all hard work to avoid and switch it; painkillers are amid the most common medications which abused. ${ }^{1}$ Among the opioids that frequently prescribed include morphine, tramadol, methadone, diamorphine, and codeine. $^{2}$

Tramadol is a opioid pain reliever that acting centrally which is mostly in use for combating pain ranging from moderate to severe. ${ }^{3}$ It is analgesic effect has a complex mechanism; as many reports suggested that opioid and non-opioid mechanisms of action is responsible for it's painkilling effects and other medical properties. ${ }^{4}$

The absorption of tramadol is $95-100 \%$ happen in small intestine namely in its upper part with bioavailability is $70 \%$ and when tramadol used in frequent doses, it is bioavailability amplified reaching to $100 \%{ }^{5}$

The metabolized of tramadol done in the liver via cytochrome p450 enzyme system and its bio transformed products are expelled by the kidneys by urine accordingly; this creates the kidney is a main goal organ of tramadol toxicity particularly in misuse and over dose cases. ${ }^{6}$ About $30 \%$ of the dose is expelled in the urine as unaffected drug, and $60 \%$ of the dosage is eliminated as metabolites while the residual drug is evacuated with the feces. ${ }^{7}$

\section{MATERIAL AND METHODS}

In the current study both tramadol hydrochloride and vitamin $\mathrm{C}$ ampoules are used and are obtained from local pharmacies in Iraq. Thirty healthy Wister albino male rats weighting about (220-250) gm. and aged three months are used in this study. These animals were kept at controlled room temperature (23-25C을 with a 12 hours light/ dark cycle and placed in plastic cages using homogenized wood shaving as bedding for acclimatization for one week before start of the experiment. The animals had allowed access of both water ad libitum and packed optimized food. The animals were divided into three groups.

Group A (control group): are daily injected with distilled water intraperitoneally (I.P). Group $\boldsymbol{B}$ (tramadol treated group) (TGI): are injected with tramadol in dose $50 \mathrm{mg} / \mathrm{kg}$ I.P. daily for four weeks. Group $\boldsymbol{C}$ (treated with tramadol + Vitamin C) (TGII): are injected with $100 \mathrm{mg} / \mathrm{kg}$ b.wt. of vitamin C I.P. daily half hour prior to tramadol injection in a dose $50 \mathrm{mg} / \mathrm{kg}$ b.wt. I.P. for four weeks.

After finishing of the fourth weeks of experiment, the animals were sacrificed and kidneys were removed and utilized for histopathological examinations, in which $10 \%$ neutral buffered formalin was used as fixator for the specimens which then processed to get paraffin sections of $5 \mu \mathrm{m}$ thickness, that stained with Haematoxylin and Eosin to be examined by light microscopic.

\section{RESULT}

Group A (Control group): Light microscopic study showed no deviation in histological findings from those seen in other normal tissues, in which kidney sections consist of renal cortex and medulla. In the cortex there is renal corpuscle, proximal convoluted tubules (PCT) along with distal convoluted tubules (DCT). Every renal corpuscle consists of blood capillaries tuft, named as glomerulus bounded by Bowman's capsule. The latter is a double walled cup formed of two layers of simple squamous epithelium, an outer parietal layer and an inner visceral one separated by a capsular space. The PCT is lined by cuboidal epithelium with spherical and basally located nuclei. The DCT is lined by cuboidal epithelium and spherical and apically located nuclei and their cytoplasm is lighter than those of PCT (Fig. 1). 
Group B (TGI): Shows atrophy and congestion of glomeruli, others showed segmentation and lobulation along with widening of bowman's space (Fig. 2). The most severe changes are observed in the tubules and mainly PCT as some of tubules are dilated, others showed marked hydropic degeneration and cytoplasmic vacuolization of tubular epithelial cells (Fig. 3). Patches of mononuclear cells (MNCs) infiltration are noticed around blood vessels and within the necrotic tubules (Fig. 4). Hyaline cast is seen within the cortex mainly inside the degenerated tubules along with hemorrhage in the interstitisum (Fig. 5).

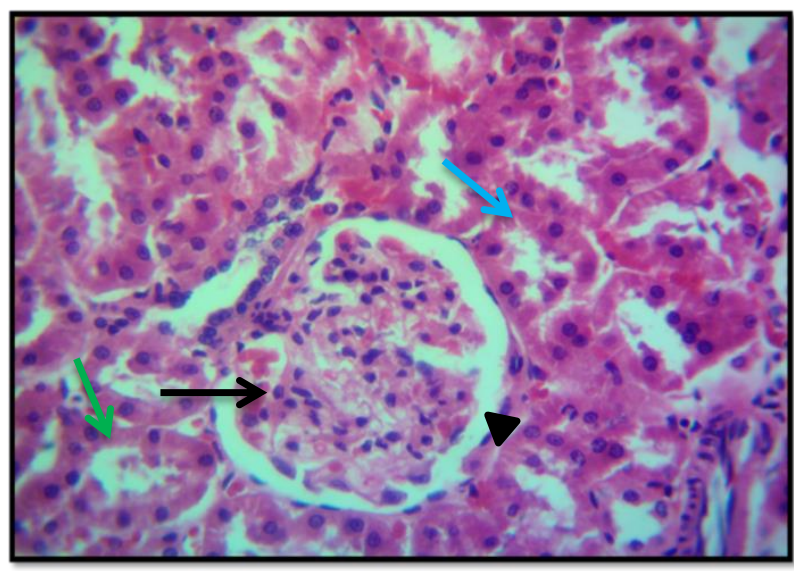

Figure 1: Photomicrograph of control group showing glomerulus (black arrow), bowman's space (arrow head), PCT (blue arrow) and DCT (green arrow) (H \& E X 400).

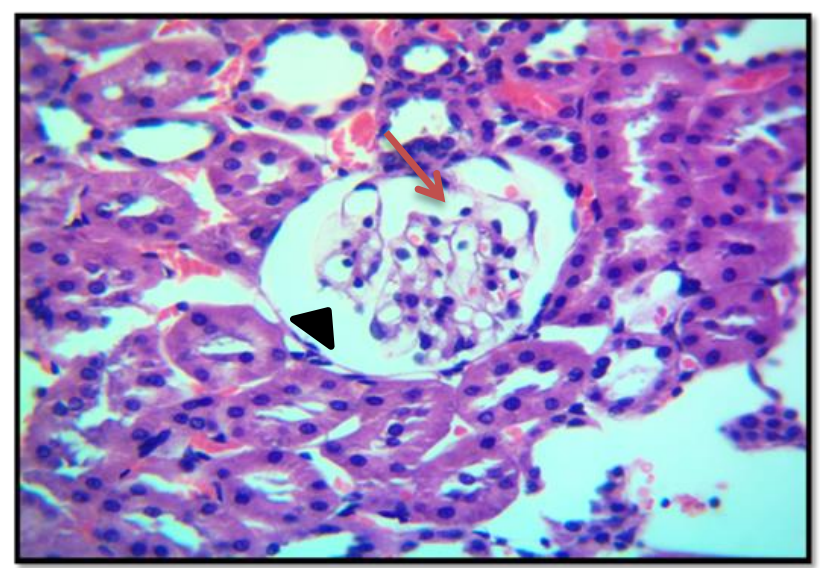

Figure 2: Photomicrograph of TGI showing glomerular atrophy with segmentation (red arrow) and widening of bowman's space (arrow head)(H \& E X 400).
Group C (TGII): shows more preserved kidney architecture, most glomeruli regained their normal appaerance (Fig. 6) Some glomeruli showed mild atrophy with mild dilatation of bowman's space (Fig. 7). Few tubules showed vacoulation in their epithelial cytoplasm (Fig. 8). Interstitial bleeding is still present but mild (Fig. 9) and little MNCs infiltration in the interstitisum of renal cortex (Fig. 10).

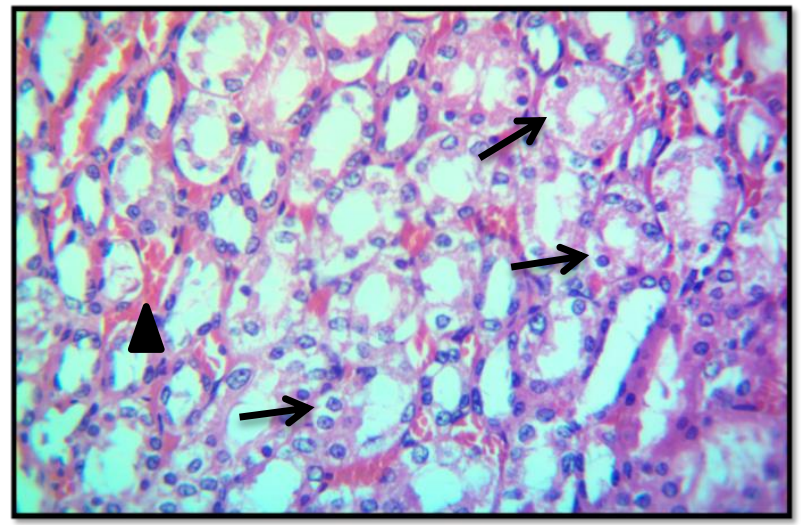

Figure 3: Photomicrograph of TGI showing extensive hydropic degeneration (black arrows), with interstitial bleeding (arrow head) (H \&E X 400).

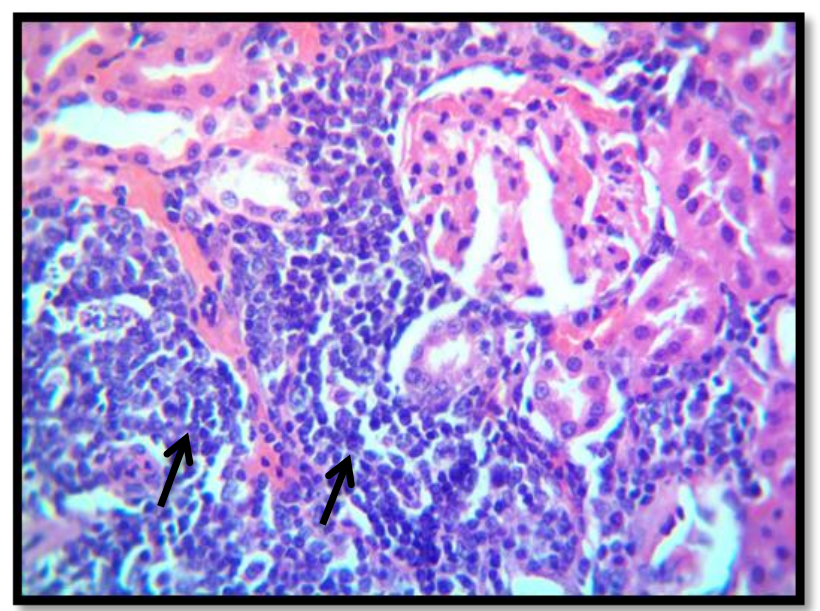

Figure 4: Photomicrograph of TGI showing MNCs infiltration within the interstitisum (black arrows) (H \&E X 400). 


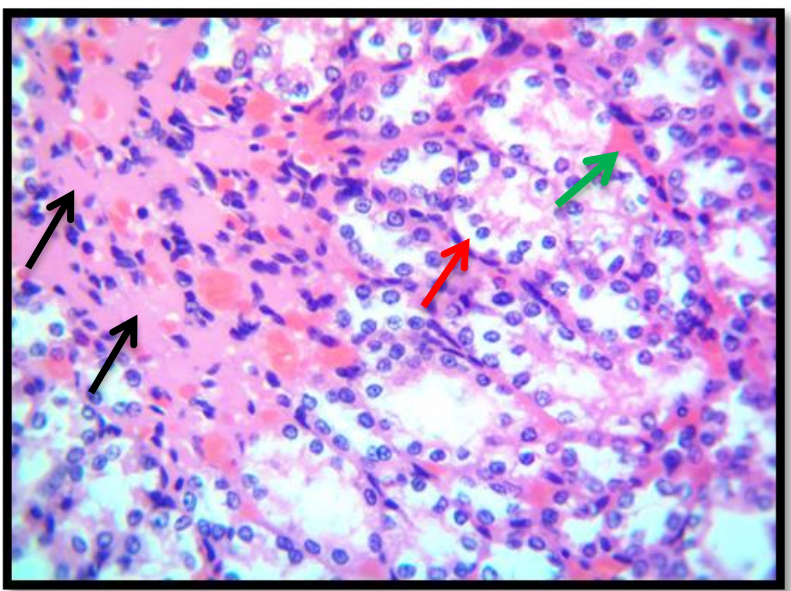

Figure 5: Photomicrograph of TGI showing hyaline casts within the degenerated tubules (black arrows), extensive vacuolar degeneration (red arrow) and hemorrhage (green arrow)(H \&E X 400).

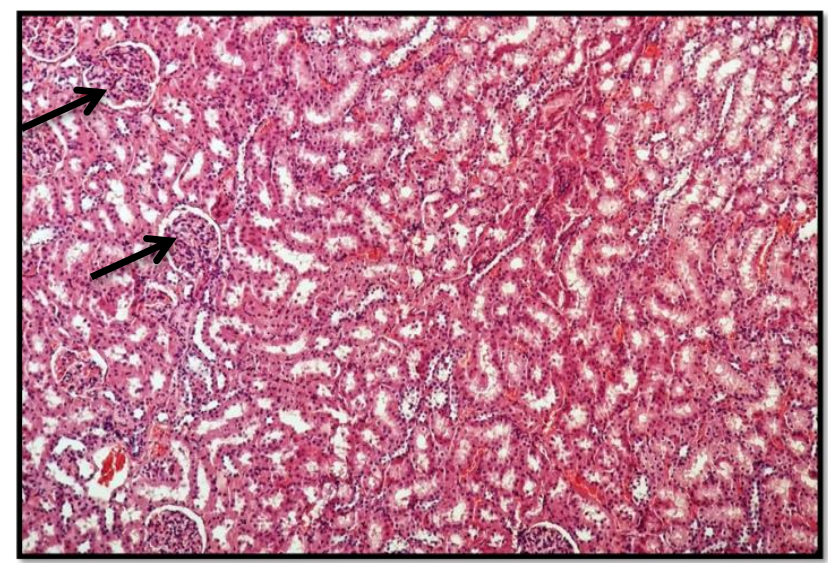

Figure 6: Photograph of kidney rat of TGll showing normal architecture of renal cortex with nearly normal looking glomeruli (black arrows ) (H\&EX100).

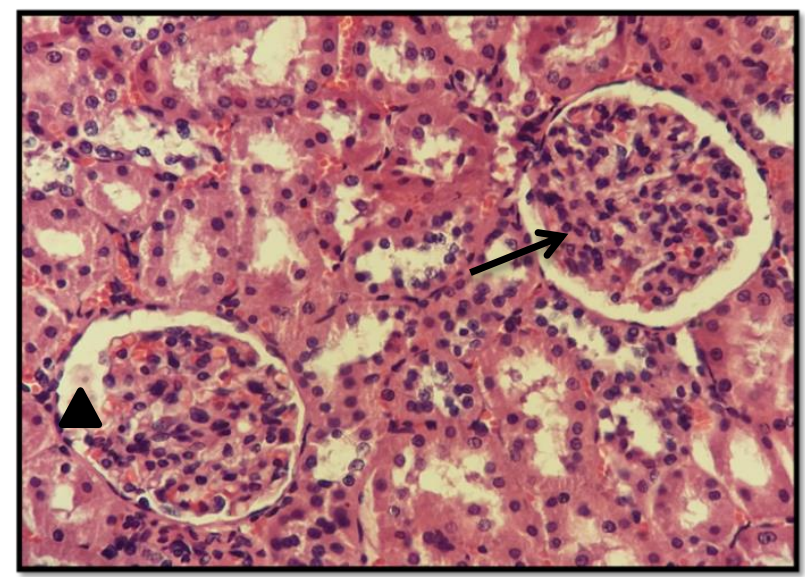

Figure 7: Photomicrograph of TG II showing mild glomerular atrophy (black arrow) with mild dilatation of bowman's space (arrow head) (H \& E X 400).

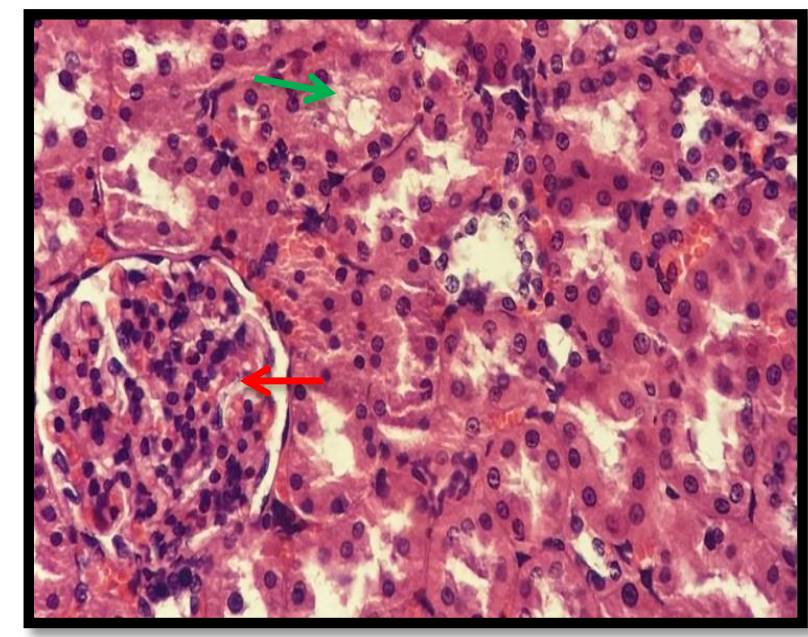

Figure 8: Photomicrograph of TGll showing nearly normal looking renal corpuscle (red arrow) while few tubules showed vacuolar degeneration (green arrow) (H\&EX400).

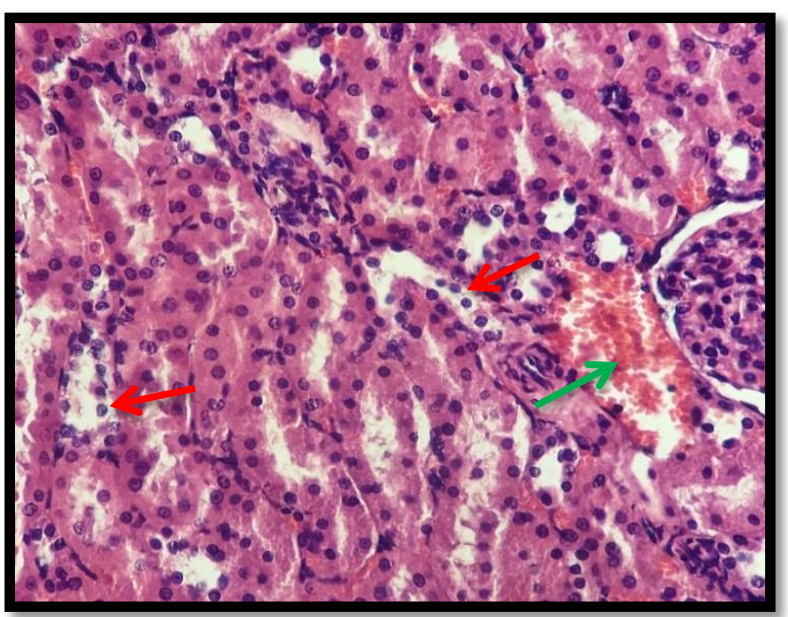

Figure 9: Photomicrograph of TG II showing interstitial bleeding (green arrow) with scattered vacuolar degeneration (red arrows) with (H \& E 400).

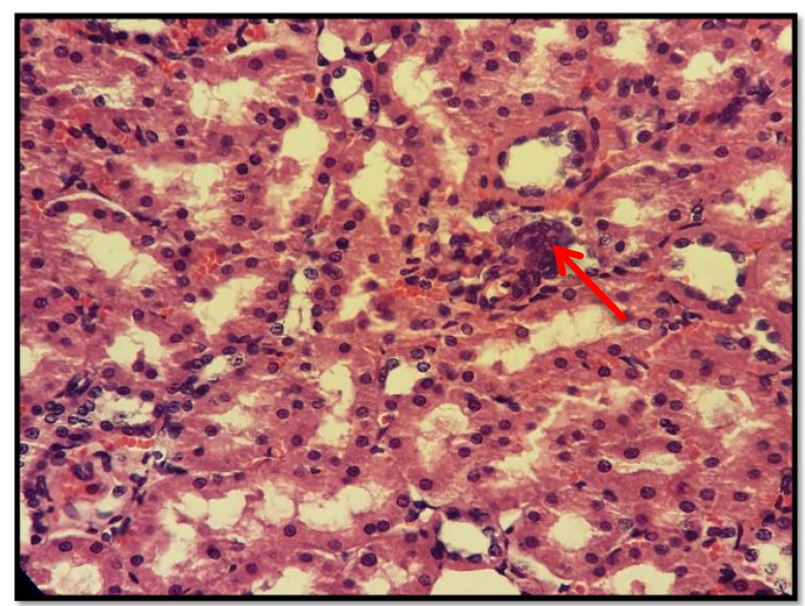

Figure 10: Photomicrograph of TG II showing mild MNCs infiltration (red arrow)(H \& E 400). 


\section{DISCUSSION}

As the kidney is the main excretory organ for drugs and chemicals, so it is susceptible to toxicity which requests for its continuous clinical assessment throughout treatment with drugs to defense against toxicity. ${ }^{8}$

In the current study there is many microscopical deviations in the tramadol treated group TGI if compared to the group A (control group), as glomerular atrophy, congested glomeruli and widening of bowman's space are in agreements with El-khateeb et al,2015 ${ }^{9}$ along with Youssef and Zidan, $2016^{10}$ findings. Some glomeruli in TGI group showed segmentation and lobulation and this run with similar finding reported by Zaghlol et al., 2018. ${ }^{11}$

The mechanism of expansion of the glomerular chamber and swelling of their lining epithelium and consequently glomerular atrophy result from drop in aerobic metabolism due to decrease in $\mathrm{O} 2$ level, as renal cells consume $\mathrm{O}_{2}$ at high rate and in need to aerobic metabolism for ATP generation. ${ }^{12}$ The cells must rely more on glycolysis in order to maintain such ATP levels, as glycolysis can leads to the accumulation of lactic acid, that causes drop in the intracellular $\mathrm{pH}$ which induce cell dysfunction of the $\mathrm{Na}+\mathrm{K}+$ ATPase followed by an influx of sodium and $\mathrm{H}_{2} \mathrm{O}$ with consequent cell swelling. ${ }^{13}$

Another important finding of the current study is the degenerative injuries in the renal tubules particularly in PCT. A similar dose i.e. $50 \mathrm{mg} / \mathrm{kg}$ b.wt produced the same degree of degeneration after treating animal for only two weeks as reported by Hafez et al.,2015. ${ }^{14}$ Also such tubular epithelial injuries induced by tramadol was reported by many studies. ${ }^{9-11}$ The mechanism of tubular damage of the renal tubules is particularly due to sensitivity of renal tubules to toxic effects, in part since they have high consumption of $\mathrm{O}_{2}$ and weak enzyme system. ${ }^{13}$ On the other hand a study done by Atici et al., $2005^{15}$ indicated that the risk of increased level of lipid peroxidation and renal damage after prolonged use of opioids, particularly morphine in the rat's kidney.

Other observation in the current study is MNCs infiltration in the renal cortex around degenerating tubules giving a picture of interstitial nephritis, this finding is in agreement with previous studies ${ }^{9,10,15}$, and this finding in addition to the other findings can be reflected as a sign of renal damage as described by Muslim Z, $2018^{16}$ while is in conflicts with this finding by Zaghlol et al., $2018{ }^{11}$ and Ali et al., $2018^{17}$ and this might be due to small dose or small dose plus short period, respectively.

The hyaline cast seen within the degenerating tubules is another finding in the present study which ascribed to the solidification of TammHorsfall mucoprotein, that secreted by the renal tubular cells. ${ }^{18}$

Many researchers proposed that vitamins, mineral selenium, ascorbic acid, quercetin and melatonin fractions in date fruit may be held responsible for renal protecting action. ${ }^{19}$ However, yet now there is no previous study about the role of vitamin $\mathrm{C}$ against nephrotoxicity induced by tramadol. In the current study using of vitamin $\mathrm{C}$, result in mild improvement in many microscopical changes induced by tramadol and showed more preserved renal architecture, with decrease in glomerular atrophy, bowman's space dilatation with degenerated tubules and mild to moderate MNCs infiltration, but congestions of interstitisum and blood vessels is still present.

Many researchers proved the protective effect of vitamin $C$ against histological changes induced by formaldehyde. $^{20,21}$ Also vitamin $\mathrm{C}$ as chemo protective agent was proved by Al-jammas S.,2011 after he injected rats with vitamin C prior to cisplatineum result in improvements in the microscopical changes induced by cisplatineum. ${ }^{22}$

The protection produced by vitamin $C$ in renal tissue in concomitant use with tramadol was recognized due to antioxidant property of vitamin C that capable to reduce lipid peroxidation which results in alleviate kidney damage by enrichment of scavenging capability of antioxidant defense organization. ${ }^{23}$ But such improvement is not bring the renal tissues to complete normality which might be due to short period of treatment with antioxidant vitamin $\mathrm{C}$ or might need a larger doses vitamin $\mathrm{C}$.

\section{CONCLUSION}

Tramadol had toxic effects on kidney structure as glomerular atrophy, widening bowman's space and degenerating tubules with vacoulation in their epithelial lining, all are improved after the addition of vitamin C. 


\section{REFERENCES}

1. Rafati $A$, Yasini SM, Dashti-Rahmatabadi $M H$, et al. Tramadol dependence rate as compared with morphine in rats. World J Med Sci 2006; 1(1): 40-3.

2. Klepstad $P$, Fladvad $T$, Skorpen $F$, et al. Influence from genetic variability on opioid use for cancer pain: a European genetic association study of 2294 cancer pain patients. Pain 2011;152(5):1139-45.

3. Nossaman VE, Ramadhyani U, Kadowitz PJ, et al. Advances in perioperative pain management: Use of medications with dual analgesic mechanisms, tramadol \& tapentadol. Anesthesiol Clin 2010;28(4):647-66.

4. Gillman PK. Monoamine oxidase inhibitors, opioid analgesics and serotonin toxicity. $\mathrm{Br} \mathrm{J}$ Anaesth 2005; 95(4):434-41.

5. Saleem R, lqbal $R$, Abbas $M N$, et al. Effects of tramadol on histopathological and biochemical parameters in mice (Mus musculus) model. J. Pharmacol 2014; 8(1):14-9.

6. Adikwu E, Ebinyo C, Nelson EC. Assessments of kidney function and morphology of tramadol diclofenac treated albino rats. Advancements in Life Sciences (als) 2018; 5( 3):104-12.

7. Eassa BI, El-Shazly MA. Safety and efficacy of tramadol hydrochloride on treatment of premature ejaculation. Asian J Androl 2013;15(1):138-42.

8. Doogue MP, Polasek TM. Drug dosing in renal disease. The Clinical Biochemist Reviews 2011; 32(2): 69-73.

9. Elkhateeb A, El Khishin I, Megahed O, et al. Effect of Nigella sativa Linn oil on tramadol-induced hepato-and nephrotoxicity in adult male albino rats. Toxicology Reports 2015; 2: 512-19.

10. Youssef SH, Zidan AHM. Histopathological and biochemical effects of acute and chronic Tramadol drug toxicity on liver, kidney and testicular function in adult male albino rats. J Med Toxicol Clin Forensic Med 2016; 1(2):40-5.

11. Zaghlol DAM. Oueis SM, Abbas NH. Effects of administration of tramadol hydrochloride on the histological structure of the kidney and the possible protective role of Curcumin in adult albino rat. Med. J. Cairo Univ 2018; 86(1):169-78.
12. Vickers AE, Rose K, Fisher R, et al. Kidney slices of human and rat to characterize Cisplatin-induced injury on cellular pathways and morphology. Toxicol Pathol 2004;32(5):577-90.

13. Cui J, Shi S, Sun $X$, et al. Mitochondrial autophagy involving renal injury and aging is modulated by caloric intake in aged rat kidneys. PloS ONE 2013; 8(7): e69720.

14. Hafez EM, Issa SY. Abdel Rahman SM. Parenchymatous toxicity of tramadol: histopathological and biochemical study. J Alcohol Drug Depend. 2015; 3(5):1-6.

15. Atici S, Cinel I, Cinel L, et al. Liver and kidney toxicity in chronic use of opioids: An experimental long term treatment model. J Biosci 2005; 30(2):245-52.

16. Muslim ZZ. The Biochemical and histological effects of tramadol on liver and kidney of albino mice. Thi-Qar Med J 2018;15(1):43-57.

17. Ali O Kh, AL-Jmor SA, Al-Graibawi MA. Effects of tramadol on histopathological and biochemical parameters in male rabbits. Am J life sci 2015; 3(3): 8590.

18. Ringsrud KM. 2001. Casts in the urine sediment. Lab Med 2001;32(4):191-93

19. Abdel-raheem IT, Abdel-ghany AA, Mohammad GA. Protective effect of quercetin against gentamycin induced nephrotoxicity in rats. Biol Pharm Bull. 2009; 32(1):61-7.

20. Abdulqader SZ, Mustafa IA . The protective role of vitamin $\mathrm{C}$ against formaldehyde induced-hepatotoxicity and nephrotoxicity in male rats. IOSR J Pharm Biol Sci 2014; 9(4): 21-6.

21. Morsy MM. The effect of formaldehyde on the renal cortex of adult male albino rats and possible protective role of vitamin C. Eur. J. Anat. 2018;22 (1): 75-84.

22. Al-jammas $\mathrm{S}$. The histological changes induced by cisplatineum on the kidney of rats (with and without Vitamin C). [M.Sc Thesis]. Collage of medicine, University of Mosul. pp.70-83.

23. Rafieian-Kopaei M. Medicinal plants for renal injury prevention. J Renal Inj Prev 2013; 2(2):63-5. 